\title{
PRODUCTIVE DYNAMIC CAPABILITY, ENVIRONMENTAL UNCERTAINTY, AND ORGANIZATIONAL PERFORMANCE: AN ANALYSIS OF MICRO AND SMALL-SIZED AGROINDUSTRIES IN SOUTHERN BRAZIL

\author{
CAPACIDADE DINÂMICA PRODUTIVA, INCERTEZA \\ AMBIENTAL E DESEMPENHO ORGANIZACIONAL: \\ UMA ANÁLISE EM MICRO E PEQUENAS \\ AGROINDÚSTRIAS DO SUL DO BRASIL
}

Submission: $27 / 11 / 2019$ Accept: 30/07/2020

\author{
Michele Raasch ${ }^{1}$ \\ Elvis Silveira-Martins ${ }^{2}$ \\ Vilmar Antonio Gonçalves Tondolo² \\ Gilnei Luiz de Moura ${ }^{3}$
}

1 Federal University of Santa Catarina, 2 Federal University of Pelotas, 3 Federal University of Santa Maria

\begin{abstract}
Purpose: The purpose of this research was to correlate the constructs of productive dynamic capability and organizational performance mediated by environmental uncertainty in micro and small agroindustries of Brazilian states such as the Rio Grande do Sul, Santa Catarina, and Paraná.

Methodology: In order to reach the expected aim, quantitative research using the survey technique was developed. The sample that was used consisting of 138 small and micro-sized of southern Brazilian agroindustries. It was performed confirmatory factor analysis and structural equation modeling for the data analysis. In order to analyze the mediation, the two dimensions of environmental uncertainty, complexity, and dynamism were analyzed each one isolated.

Findings: The outcomes show a positive correlation between productive dynamic capability and performance in rural agroindustries. The mediation of both complexity and dynamism presented a positive statistical significance, that is the environmental uncertainty mediated the relationship. This study suggests that the agroindustries productive dynamic capability contributes to its performance, and the perception of environmental uncertainty influences this relation.

Originality/Value: The study contributes to the dynamic capabilities' theory, advancing and providing new empirical evidence to the investigations on dynamic capabilities, specifically on productive dynamic capability, when relating the performance construct in micro and small agroindustries. It also contributes to the environmental uncertainty field through its mediating effect on the relation between productive dynamic capability and organizational performance.

Keywords: Productive dynamic capability; Environmental uncertainty; Organizational performance; Micro and small-sized agroindustries; Agribusiness.
\end{abstract}




\section{RESUMO}

Objetivo: O objetivo da pesquisa foi correlacionar os construtos de capacidade dinâmica produtiva e desempenho organizacional mediados pela incerteza ambiental em micro e pequenas agroindústrias de estados brasileiros como Rio Grande do Sul, Santa Catarina e Paraná.

Metodologia: Para alcançar o objetivo foi desenvolvida uma pesquisa quantitativa, com o uso da técnica survey. A amostra é composta por 138 agroindústrias de micro e pequeno porte da região sul do Brasil. Para a análise de dados foram realizadas a análise fatorial confirmatória e modelagem de equação estrutural. Para a análise da mediação, analisou-se as duas dimensões da incerteza ambiental separadamente, complexidade e dinamismo.

Resultados: Os resultados apresentam correlação positiva entre a capacidade dinâmica produtiva e o desempenho nas agroindústrias rurais. A mediação tanto da complexidade, quanto do dinamismo apresentaram significância positiva, ou seja, a incerteza ambiental é mediadora na relação. A pesquisa sugere que a capacidade dinâmica produtiva das agroindústrias contribui para o seu desempenho, e a percepção da incerteza ambiental influencia nesta relação.

Originalidade/Valor: A pesquisa contribui com a teoria das capacidades dinâmicas, avançando e fornecendo novas evidências empíricas às pesquisas sobre as capacidades dinâmicas, mais precisamente a capacidade dinâmica produtiva, ao relacionar o construto com o desempenho, em micro e pequenas agroindústrias. Assim como contribui para o campo da incerteza ambiental, ao verificar seu efeito mediador na relação entre a capacidade dinâmica produtiva e o desempenho organizacional.

Palavras-chave: Capacidade dinâmica produtiva; Incerteza ambiental; Desempenho organizacional; Agroindústria de micro e pequeno porte; Agronegócio.

\section{INTRODUCTION}

Some organizations stand out from others, even in similar backgrounds. The understanding of how these organizations obtain such a competitive advantage is a motivating subject of research in the field of strategy. In order to explain this difference, the Resource-Based View theory (RBV) highlights the generation of competitive advantage through the strategic use of the organization's internal resources (Barney, 1991). The theory in dynamic capabilities arises as an evolution of the RBV when inserting the organizational environment in its analysis, therefore, it seeks to explain the competitive advantage in turbulent environments (Barreto, 2010).

Productive dynamic capability is one of the specific capabilities that arose from the general theory of dynamic capabilities, through the study by D'Avila and Silveira-Martins (2017). Its purpose is the search for knowledge of internal skills that are linked to production. Thus, the organization can anticipate the adaptations of the productive processes, and consequently, drive advantage over the market. The validation of a research tool on productive dynamic capability, developed and validated by D'Avila and Silveira-Martins (2017), opens a gap in the literature for the propagation of studies that address the theme.

Until that moment the study in productive dynamic capability was carried out only by D'Avila and Silveira-Martins (2017), which was based on the theory of dynamic capabilities realized the need for a construct that explains the competitive advantage linked to the productive chain of industries. The study was performed with breweries in the states Brazilians of Rio Grande do Sul, Paraná, São Paulo, Minas Gerais, and Bahia. With this, there is a gap to analyze the dynamic productive capability in other industrial backgrounds and also possible relationships with other constructs.

However, it is necessary to extend beyond investigating in isolation the dynamic capabilities, it is necessary to analyze the relationship with the external environment of the organization and with the organizational performance. Therefore, studies on the relationship between productive dynamic capability and organizational performance, and with the mediation of environmental uncertainty support a better understanding of dynamic capabilities. Researches of this type are 
necessary to clarify how a company adapts itself and how it stands out (Alves, Barbieux, Reichert, Tello-Gamarra, \& Zawislak, 2017).

The agroindustry segment deals with difficulties and uncertainties that impact on its survival and performance. The agroindustries must constantly adapt to the laws of the sector, as well as the seasonality and perishability of their raw material (Fernandes, 2014). Some businesses are not getting riskier, but business environments are increasingly more uncertain, which is a challenge for managers, as it demands from them confrontation responses focused on these environments (Teece \& Leih, 2016). For that reason, they are prone to develop their productive dynamic capability to maintain a propitious performance and competitive advantage over their competitors. Small and medium-sized enterprises play a key role in economic development (Roxas, Ashil, \& Chadee, 2017). Additionally, the agroindustries support the job creation and income to the families of their region, and also the sustenance of family farmers (Foguesatto \& Machado, 2017). This is evident in the announcement by the Advanced Studies Center in Applied Economics (CEPEA) (2018), of a growth in production and employment in the agro-industry sector since the second half of 2017.

Agribusiness is an important influencer of the Brazilian economy, agroindustries are responsible for part of this influence. Brazil had about 571,643 rural establishments with processing, $23.3 \%$ of them were located in the Brazilian southern region, behind only the Northeast region with 49\% of establishments according to the Brazilian Institute of Geography and Statistics (IBGE) (2006). According to IBGE (2017) data, rural agroindustries in Brazil were responsible for the production of 152,694 liters of cane brandy, 27,760 tons of regional jams, and jellies. The states that make up Brazilian southern are the Rio Grande do Sul, Santa Catarina, and Paraná and it was responsible for the production of $96 \%$ of grape wine $(108,675 \mathrm{I}), 30 \%$ of canned vegetables $(11,520 \mathrm{t})$ and, by $26 \%$ of sausage production $(9,467 t)$, compared to national production according to IBGE (2017).

Given the above, this research aims to verify the hypothesis that the productive dynamic capability of small and micro-sized agroindustries has a positive effect on their performance and, when this association is mediated by the factors of environmental uncertainty - complexity and dynamism - there will be interference in correlation.

This research is based on the recommendations of Fischer, Gebauer, Gregory, Ren and Fleisch (2010), Silveira-Martins (2012), Freitas and Salermo (2018), on the need for discoveries about dynamic capabilities, for better understanding. Such as new evidence on the relationship between dynamic capability and performance (Takahashi, Bulgacov, \& Giacomini, 2017). On the need for studies involving environmental influences in organizational analysis (Aragón-Correa \& Sharma, 2003; Escobar, 2012; Shoham, Asseraf, Lev, \& Fiegenbaum, 2017). And about the opportunity to develop studies on the productive dynamic capability and its relationship with other constructs, to support in the theoretical and managing advance of this newer theory, until that moment used only in the study that developed it.

\section{LITERATURE REVIEW}

\subsection{Productive Dynamic Capability}

The dynamic capabilities theory arise from the gap left in the RBV theory, moves forward by considering the organizational environment in the achievement of competitive advantage inserting robustness to empirical research in the last decades (Eisenhardt \& Martin, 2000; Wang \& Ahmed, 2007; Ambrosini \& Bowman, 2009). The common definition used for dynamic capabilities were made by Teece, Pisano, and Shuen (1997), seen as the company's ability to integrate, construct, 
and reconfigure its internal and external competencies in changeful environments in order to drive competitive advantage. It deals with "doing the right things", it enables the company to perform its activities to manufacture high demand products. (Teece \& Leih, 2016, p. 7).

Such capabilities can still be considered as the results of the sum of other company-specific capabilities and their routines (Eisenhardt \& Martin, 2000; Andreeva \& Chaika, 2006; Wang \& Ahmed, 2007; Freitas \& Salermo, 2018). The efficiency of organizations will depend on how they are able to combine their different capabilities (Alves et al., 2017). Based on the studies on dynamic capabilities, D'Avila and Silveira-Martins (2017) validated a measurement scale for productive dynamic capability, with that, a new specific dynamic capability emerges in the literature.

The authors D'Avila and Silveira-Martins (2017), carried out their research with microbreweries in several regions of Brazil, where they identified eight variables of productive capabilities: (a) use of automated equipment for production; (b) use of technological equipment for production; (c) skilled labor for production; (e) product diversity; (f) distribution; (g) optimized production; (h) control in the production process; (i) does not lose quality in any of the productive processes. The productive dynamic capability is defined by D'Avila and Silveira-Martins (2017, p. 04), as the "set of all internal capabilities of the organization linked to the productive system, from its beginning to the end, and the management of their forces is concise in response to environmental uncertainty".

Among the variables that are part of this capability is the automation of production, the use of technological equipment for production, skilled labor, which result in optimized production, guaranteeing the quality of the products (Fleury, 1989), it comes from the component that guarantees not to lose the quality in any production process.

The product diversity may be able to generate better economic performance for the company (Grant \& Jammine, 1988). The distribution channels of this production must meet the customer demands, delivering the products or services with excellence, in the right place and at the right time (Costa \& Almeida, 2007), to meet customer demands may positively impacting their brand and loyalty (Yoo, Donthu \& Lee, 2000).

Process innovations linked to machinery and equipment refers to the application of new or improved production methods (Snyder, Witell, Gustafsson, Fombelle, \& Kristensson, 2016). Such innovations influence the reduction of losses during the production cycle, higher productivity and, good usefulness, and good quality (Snyder et al., 2016).

The authors Mundim et al. (2002) report that in order to be effective and efficient in production, it is essential to have a qualified and multifunctional team, interacting in all production processes, developing products with the required specificities by the market. The availability of skilled labor may also increase the likelihood of the successful performance of innovative activities (Collins \& Reutzel, 2017).

The process control of the production seeks to meet the production requirement's to the maximum extent possible, with a flow of information sharing between departments, aiming to ensure a more efficient production (Bonney, 2000). Based on these eight variables, the construct productive dynamic capability seeks to identify if the company is using its internal capabilities linked to the production to improve its strategies and consequently their performance.

\subsection{Environmental Uncertainty}

To remain visible and competitive, companies must continually adapt to the environment in which they are placed (Duncan, 1972). The perception of the environment is influenced by the background of the environmental organization's uncertainty, which may affect its results (Dess \& 
Beard, 1984; Boyd \& Fulk, 1996; Priem, Love \& Shaffer, 2002; Gardelin, Rossetto \& Verdinelli, 2013).

Environmental uncertainty is made up of the lack of information on environmental factors and the lack of predictability in consequence of a certain event (Duncan, 1972; Aldrich \& Pfeffer, 1976; Goll \& Rosheed, 2005). According to Teece, Peteraf, and Leih (2016), the organization's uncertainty degree has increased as the economy becomes more advanced allowing the opening of new business opportunities anywhere. An uncertain environment does not provide the manager with the ability to predict future events, and neither the quantity nor features of potential impacts of these events, which are not always negative (Teece \& Leih, 2016).

Uncertainty is a result of two factors, the dynamism and complexity of the environment (Duncan, 1972; Dess \& Beard, 1984; Cannon \& St. John, 2007). The dynamism of the environment is understood as the unpredictability and the swift elements change such as the customer needs, technology, suppliers, scope of work for competitors, among others (Dess \& Beard, 1984; Carvalho \& Rossetto, 2014; Kovach, Hora, Manikas, \& Patel, 2015; Mikalef \& Pateli, 2017; Neirotti \& Raguseo, 2017).

The complexity of the environment may be considered as the diversity of factors or information that influence the decision-making processes (Duncan, 1972; Dess \& Beard, 1984; Mikalef \& Pateli, 2017). Increasing the number of these factors that occur in a certain context may increase the difficulty of managers to realize their impact on their company (Harrington \& Kendall, 2007).

\subsection{Relationship between Hypotheses and Constructs}

The dynamic capabilities facilitate organizations to outperform their competitors in the long-term (Wang \& Ahmed, 2007; Silveira-Martins \& Zonatto, 2015; Wang, Senaratne \& Rafiq, 2015). The literature presents results of several specific dynamic capabilities relationship to performance (Wu, 2006; Qureshi, Aziz \& Mian, 2017; Silveira, 2017).

Dynamic capabilities mediated the relations between knowledge management and organizational performance, and strategic leadership and performance at Najmi, Kadir e Kadir (2018) studies. The authors analyzed about 100 hospitals through structural equation analyses.

In the study carried by Hernández-Perlines, Moreno-Garcia, and Yáñez-Araque (2017), the absorptive dynamic capability moderated the relationship between performance and entrepreneurial orientation. The absorptive dynamic capability performed a direct and significant relationship in the performance of 157 dairy farms in Spain, according to Bastanchury-López, De-Pablos-Heredero, Montes-Botella, Martín-Romo-Romero, and García (2020) study.

The researchers Mikalef and Pateli (2017), in their study, found that the relationship between IT dynamic capabilities and organizational performance is mediated by organizational agility (market capitalization and operational adjustment agility). The significant relationship between marketing dynamic capability and performance is found in the study by Qureshi, Aziz, and Mian (2017), conducted in 253 small and micro-sized new technology-based companies in Turkey, supporting the research that understanding of the relation of dynamic capabilities with firm performance.

The dynamic capability was positively related to organizational performance, as shown in the studies led by Chen, Fung, and Yuen (2019), in a sample of 103 logistics companies from Hong Kong, and Ferreira, Coelho, and Moutinho (2018), that conducted it with 387 logistics companies from Portugal. The dynamic capability also has proven to be a source of competitive advantage, when analyzed in small businesses in Indonesia (Khouroh, Sudiro, Rahayu \& Indrawati, 2019).

Through the reports of such specific dynamic capabilities related to performance, the present research sought to verify the possible relationship between productive dynamic capability and the performance of agroindustries: 
$\mathbf{H}_{\mathbf{1}}$ : There is a positive correlation between performance and productive dynamic capability in agroindustries in southern Brazil.

It is necessary to consider that environmental uncertainty can affect strategy formulation, interfering in the manager decision-making, who need to adopt measures to overcoming environmental turbulence (Smart \& Vertinsky, 1984), and this way influence on the performance of organizations (Milliken, 1987; Lumpkin \& Dess, 1996; Priem, Love \& Shaffer, 2002; Gardelin, Rossetto \& Verdinelli, 2013).

The understanding of environmental uncertainty is the organization management's responsibility (Silveira-Martins \& Tavares, 2014), which can impact on adopted strategies (Aldrich \& Pfeffer, 1976; Aragón-Correa \& Sharma, 2003; Carvalho \& Rossetto, 2014). Success in perception is necessary to ensure superior performance in organizations (Boyd \& Fulk, 1996; Priem, Love \& Shaffer, 2002; Silveira-Martins \& Rossetto, 2018). Based on these ideas, Silveira (2017) has identified that the level of managers' perception of environmental uncertainty is proportional to the level of performance of the organization.

According to Schilke (2014), dynamic resources may be able to generate a competitive advantage for the organization, according to the current level of environmental dynamism. Thus, environmental dynamism can increase the development, the importance, and use of dynamic capabilities, encouraging the use of dynamic resources in these contexts (Barbero \& Ramos; Chiang, 2017; Frank, Güttel \& Kessler, 2017).

Highly dynamic markets can affect organizational performance, for example in the innovation capability, efficiency, and flexibility of production (Wu, 2006). In their study Akgün, Keskin, and Byrne (2008) found out that the relationship between emotional ability and organizational performance was influenced by environmental dynamism. As well as the managers perceive environmental complexity may reflect on firm performance (Boyd \& Fulk, 1996). The two factors that make up environmental uncertainty were analyzed separately, dynamism, and complexity, in order to individually identify their influences. According to the discussion presented here, it is sought to verify:

$\mathbf{H}_{2 \mathrm{a}}$ : Environmental complexity is a mediator in the relationship between productive dynamic capability and organizational performance in the agroindustries from the Brazilian southern region.

$\mathbf{H}_{\mathbf{2 b}}$ : Environmental dynamism is a mediator in the relationship between productive dynamic capability and organizational performance in the agroindustries from the Brazilian southern region.

\section{METHOD}

The research is defined as quantitative; it uses the survey technique and non-probabilistic convenience sample. The sample is composed of 138 micro-sized (131 agroindustries) and smallsized ( 7 agroindustries) agroindustries from the states of Rio Grande do Sul (118 agroindustries), Santa Catarina (17 agroindustries), and Paraná (3 agroindustries). The sample size is under the standards reported by Hair, Black, Babin, Anderson and Tatham (2009).

The southern region of Brazil, as well as the size of the agroindustries, was selected for the study due to its importance for the development in this region. For the classification regarding the size of agroindustries, the classification recommended by SEBRAE (2013) was considered, micro-sized companies that have up to 19 employees and small companies that have 20 to $99 \mathrm{em}$ ployees. Micro and small agroindustries arise as a way of increasing the income of rural families, and also as a way of adding value to products in nature, through agro industrialization (Foguesatto 
\& Machado, 2017).

The respondent was asked to indicate whether the agribusiness was considered as a rural family, or not. Over the sample's totality, 112 agroindustries in the results were defined as rural family, 2 small and 110 micros. According to IBGE (2017), rural agroindustries are those whose sale of the final product is made by the producer. These can be considered to family, with predominant family members labor, or non-family, where the hired labor predominates (Waquil et al., 2014).

The establishing year of the surveyed agroindustries ranges from 1925 to 2018 . And they are producers of the following products: cookies, bread, regional jam, jelly, honey derivatives, cachaça, beer, distilled drinks, canned vegetables, juices, wines, sausages, cheese, rapadura. The respondents' profiles consisted of 78 male and 60 female respondent managers. Regarding education, the majority of respondents, 43 managers, reported having completed high school, of these 2 of them also have completed technical courses, one of them in agriculture and the other one in agribusiness. Next, 35 respondents stand out to complete higher education.

The data collection instrument of the productive dynamic capability construct is composed of the adaptation of an instrument developed by D'Avila and Silveira-Martins (2017). The instrument validated by Carvalho and Rossetto (2014), already used by other researchers such as Müller (2016) and Silveira (2017), was used to measure the perception of environmental uncertainty. We used scales of 1 (minimum agreement/perception) to 6 (maximum agreement/perception) points for both constructs, where the interviewed should report about their agreement/perception regarding the affirmative.

The organizational performance construct was measured by an adaptation of the instrument proposed by Gupta and Govidarajan (1984), already validated with the adaptations by Muniz Filho (2011), Silveira-Martins (2012), Silveira-Martins, Rossetto, and Añaña (2014), Lizote and Verdinelli (2014; 2015), Müller (2016), Silveira (2017), Klinger (2018). Two parts make up the construct, one related to the importance of each item from the manager's viewpoint, and the other one is related to the satisfaction of a given item with its agroindustry. The items were the same in both parts. Therefore, a scale of 1 (minor importance/satisfaction) to 6 (major importance/satisfaction). For the data analysis, these two values were multiplied, according to the equation proposed by Gupta and Govidarajan (1984). Table 1 shows the variables for each questionnaire construct.

A pre-test was performed with three professionals, before data collection to verify the questionnaire's understanding. The questionnaire was applied after making the necessary adjustments in the instrument of collection. The data collection was performed with agroindustries managers in loco in agroindustries or at exhibitions totaling 96 questionnaires collected in this way, and via e-mail totaling 42 questionnaires collected, out of a total of 267 questionnaires sent via e-mail.

Even though the instruments used have already been the subject of further research, it was we chosen to verify the internal consistency of the whole scale using Cronbach's alpha measurement. According to Hair, Anderson, Tatham and Black. (2007), this is the widest measurement, and the minimum value used to and accepted to validate the reliability should be $>0.6$, which was confirmed for all constructs of this research, certifying the scale's adjustment. 
Table 1 - Constructs and variables questionnaire

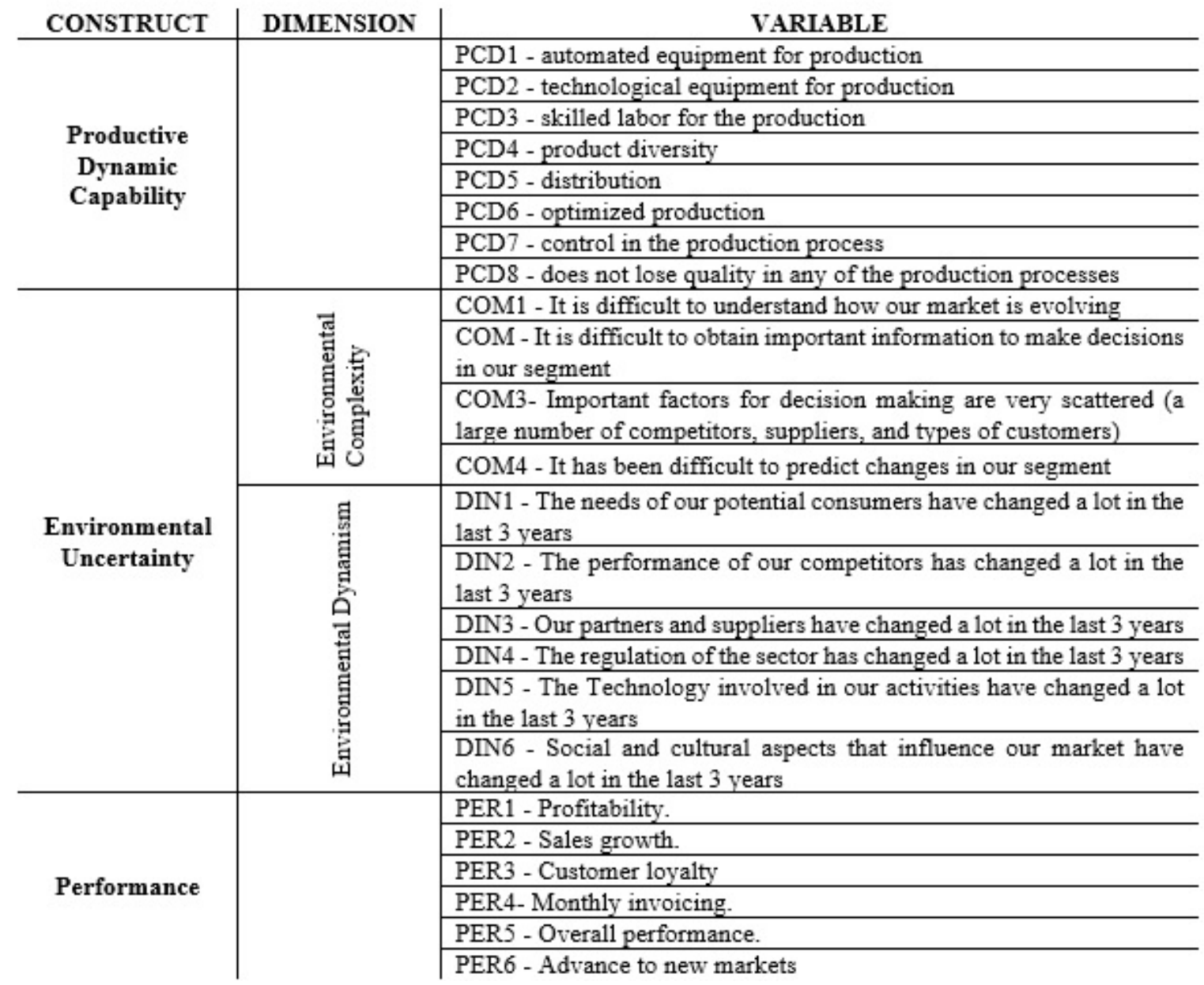

Source: Self elaboration (2020), based on Gupta and Govidarajan (1984), Carvalho and Rossetto (2014) and D'Avila and Silveira-Martins (2017).

To perform the confirmatory factorial analysis, based on Hair et al. (2009) recommendations, the following adjustment items were used: Root Mean Square Error of Approximation (RM$\mathrm{SEA} \leq 0,100)$, Tucker-Lewis Index $(\mathrm{TLI} \geq 0,900)$, that precedes the Comparative Fit Index $(C F I \geq 0,900)$. According to Hair et al. (2009), the expected values should not be considered absolute, they serve only as a horizon for the best model fit.

Since the Chi-square test $\left(x^{2}\right)$ is sensitive to the sample size (Fan, Thompson \& Wang, 1999; Hair, Anderson, Tatham, \& Black, 2007), for those samples close to 100 it can cause imprecise outcomes and underachievement in other validations (Hair et al., 2007). And that the MPlus ${ }^{\circledR}$ software was indicating that the $x^{2}$ values of the database could not be considered as absolute, it was decided not to perform the test. The Microsoft Excel 2010, software MPlus ${ }^{\circledR}$ version 7, and AMOS 16.0 were used for tabulation, statistical analysis, and graphical data construction respectively.

\section{DATA ANALYSIS}

After the data collection, to certify that the collected data were not filled in randomly, the analysis of the variables was performed individually and grouped. Thus, an average of $s=1.4985$ was found, considered by the researchers as reflecting that the questionnaires were answered randomly. 
First, it was performed an individual factorial analysis of each model construct, to validate the theory applied in each construct (Hair, Black, Babin, Anderson, \& Tatham, 2009), and lastly the factor confirmatory analysis to the complete model. The analysis of productive dynamic capability constructs revealed CFI (0.748) and TLI (0.647) with values outside the target standards $(\geq 0.900)$, as well as the RMSEA $(0.228)$ higher than expected $(\leq 0,100)$. In order to test an optional model for the construct, to identify a model that best fits the research, simulations were carried out disregarding the variables PCD1 (0.687), PCD2 (0.530), PCD3 (0.440), PCD4 (0.584), PCD5 (0.653).

In the optional model the coefficients of the variables were statistically significant, and also indicated an increasing to their loads, PCD6 (from 0.711 to $0.756, p$-value $=0.000<\alpha=0.05$ ), PCD7 (from 0.726 to $0.848, p$-value $=0.000<\alpha=0.05$ ), PCD8 (from 0.635 to $0.711, p$-value $=0.000<\alpha=0.05$ ). As well as the CFI $(1,000 \geq 0,900), \operatorname{TLI}(1,000 \geq 0,900)$ and RMSEA $(0,000 \leq 0,100)$ whose indicators presented a good fit for the construct. Although the CFI and TLI rates of the optional model have maximum quality values, they still cannot be considered as transgressors (Hair et al. 2009). Thus, the optional model provides the best option for carrying out this research, since it presents RMSEA rates $(0.000)$ in expected patterns $(\leq 0,100)$.

The confirmatory analysis of the environmental complexity construct revealed adequate indicators of CFI $(1,000 \geq 0,900)$, TLI $(0.999 \geq 0.900)$, and RMSEA $(0.012 \leq 0.100)$, but still, simulations were performed to test a model that best fits the research. For this reason, the coefficients of the variables were analyzed to reduce the variables of a lower coefficient (Hair et al., 2009), to test an optional model.

To the optional model, the variable COM3 $(0.475)$ was disregarded for presenting a factorial load lower than the others variables, the optional model provided rates with better adjustment than the initial model CFI $(1,000 \geq 0,900)$, TLI $(1,000 \geq 0,900)$, and RMSEA $(0.000 \leq 0.10)$. The analysis showed that the considered variables behaved in a significant way in the optional model COM1 $(0,705, p$-value $=0.000<\alpha=0.05), \operatorname{COM} 2(0.680, p$-value $=0.000<\alpha=0.05)$ and COM4 $(0.631, p$-val$u e=0.000<\alpha=0.05)$.

The coefficients of the indicators were analyzed, $p$-values, divergence, and error in order to identify possible abnormalities in variables that showed maximum adjustment, for this phenomenon to have happened. No difference was identified in the literature, the optional model will be used for the environmental complexity construct since it presents a better adjustment.

The environmental dynamism constructs analysis shown a CFI indicator $(0.916 \geq 0.900)$, but TLI $(0.860)$ lower than expected $(\geq 0,900)$, also, the RMSEA rates $(0.153)$ was higher than expected $(\leq 0,100)$. Therefore, the analysis of the coefficient of each one variable that makes up the dynamism construct was carried out with the purpose of performing simulations to the construction of an optional model that best fits the research.

When disregarding the variables DIN2 (0.541) and DIN6 (0.643), with lower coefficients it was noticed that in the absence of them the optional model provides better results. The optional model provides the variables DIN1 $(0,444, p$-value $=0.000<\alpha=0.05)$, DIN3 $(0.572, p$-value $=0.000<\alpha$ $=0.05)$, DIN4 (0.729, $p$-value $=0.000<\alpha=0.05)$ and DIN5 $(0.694, p$-value $=0.000<\alpha=0.05)$, statistical ly significant. The optional model provides reliable indicators CFI $(0.992 \geq 0.900)$, TLI $(0.975 \geq 0.900)$, as well as RMSEA $(0.071 \leq 0.100)$. The optional model will be used for this reason to explain the environmental dynamism in the research.

The organizational performance constructs provided satisfactory results, with CFI indicators $(0.940 \geq 0.900)$, TLI $(0.900 \geq 0.900)$, and RMSEA $(0.073 \leq 0.100)$ fixed, so it was decided not to carry out simulations to this construct.

The general analysis of the model was used the optional models to the constructs productive dynamic capability and environmental uncertainty, and to the organizational performance 
construct the model initially proposed. The indices found in the general model initially proposed are under the desired values. As CFI $(0.927 \geq 0.900)$, TLI $(0.912 \geq 0.900)$, and RMSEA $(0.084 \leq 0.10)$, the overall model was considered reliable and adjusted for the research. Figure 1 presents the general model, with loads of each variable, used in this research.

Figure 1 - General research model

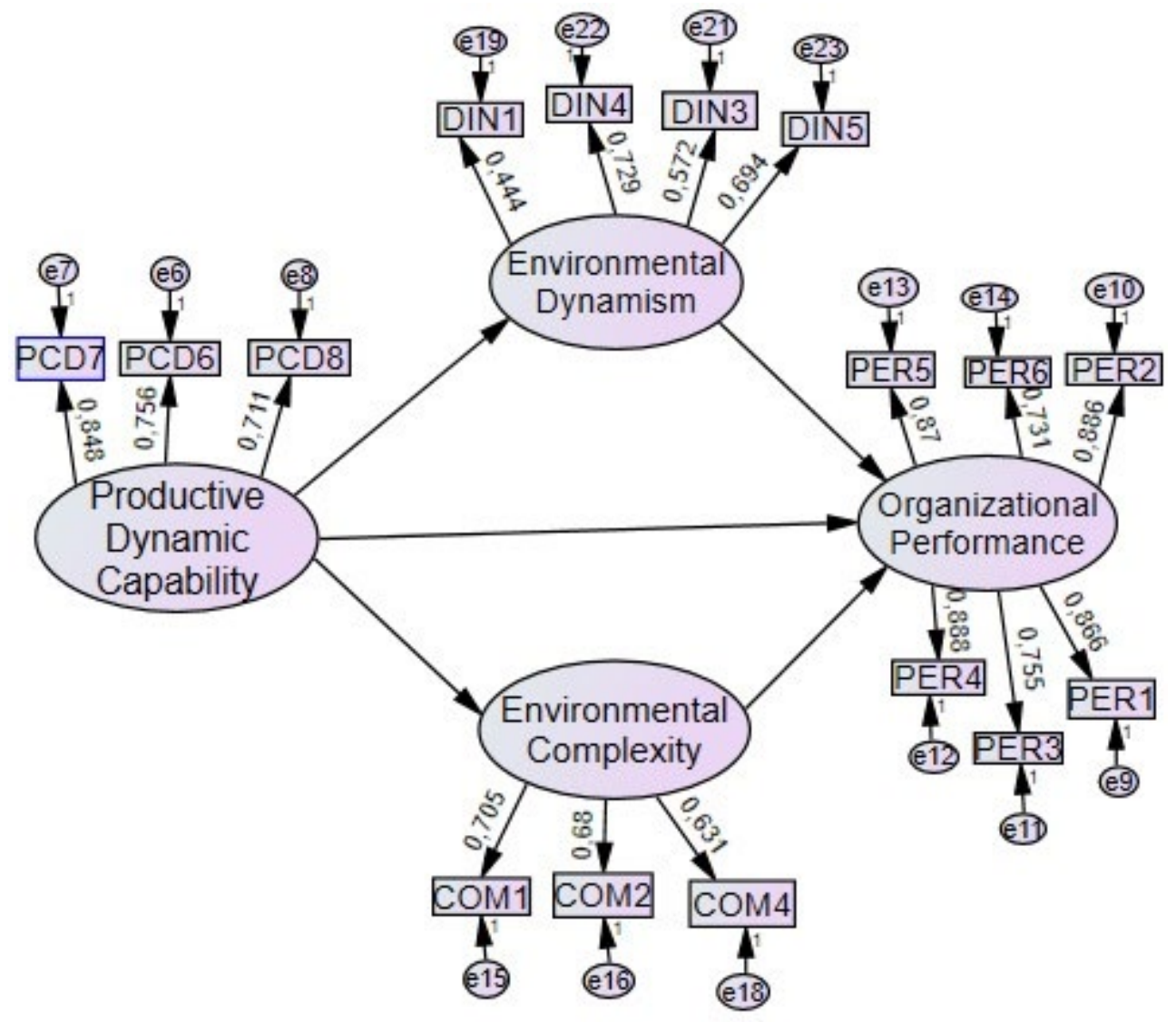

Source: Self elaboration (2020).

The general model is considered fit to the research, being used to the hypotheses tests and correlation of the constructs.

\subsection{Analysis of hypothesis testing}

The hypothesis test is used to discuss the outcomes because empirical evidence also requires theoretical validation for the model measured (Hair et al., 2009). Table 2 has the purpose of presenting the results of hypotheses, with their coefficient, significance, and association level.

Table 2 - Hypothesis test

\begin{tabular}{l|l|l|l|l}
\hline Hypothesis & Coefficient & p-value & Association & Result \\
\hline $\mathrm{H}_{1}:$ & 0.375 & 0.000 & Positive & Confirmed \\
\hline $\mathrm{H}_{2 \mathrm{a}}$ & 0.000 & 1.000 & Mediation & Confirmed \\
\hline $\mathrm{H}_{2 b}$ & 0.000 & 1.000 & Mediation & Confirmed \\
\hline
\end{tabular}

Source: Self elaboration (2020). 
From the analysis, it was possible to confirm $\mathrm{H} 1$, in other words, there is a positive and significant correlation ( 0.375$)$ between the productive dynamic capability and the agroindustries surveyed performance ( $p$-value $=0.000<\alpha=0.05$ ).

Barney (1991), points out in family businesses the participation in management is a unique resource, thus, generating competitive advantage. Such a statement is relevant because $81 \%$ of the sample is made up of family agroindustries. To the competitive advantage to occur, the organization needs to develop new capabilities and use existing capabilities while maintaining synergy between them (Teece, Pisano \& Shuen, 1997).

In Desarbo, Benedetto, Song and Sinha (2005) perspectives, one way of guaranteeing organizational performance in uncertain environments is to use all dimensions of the strategy capacity. Among them, according to the authors, the technological capability related to the efficient production process, cost reduction, development of new products; the management capability related to the logistics systems, and quality control. These dimensions and variables correspond to the productive dynamic capability variables.

This result support other results from research carried with other types of specific dynamic capabilities and performance. The research carried out in Escobar's thesis (2012), for example, where the author identified positive results to the relationship between dynamic absorption capability and dynamic innovation capability with performance. In other words, how bigger acquired knowledge, and organizational innovation, how bigger the performance tends to be.

In this study, how bigger the organization's dynamic capability to acquire and reconfigure its resources and skills related to production such as product diversification, investment in distribution, quality in production, acquisition of automated and technological equipment, the performance tends to go along that proportion. Since efficiency in the production process reduces costs for the organization, and finally increases its competitiveness (Day, 1994).

The outcomes point out that agroindustries are capable of producing their products with their production capability, investing in diversity, quality, and technology to anticipate customer needs and innovate to maintain their differential. According to the authors Rojo, Stevenson, Montes and Perez-Arostegui (2018), companies can achieve higher levels of flexibility in the supply chain through specific dynamic capabilities. As is the case in this study which has identified that companies can achieve superior performance through productive dynamic capability.

On the other hand, the results of $\mathrm{H} 1$ contradicts the results of the authors Mikalef and Pateli (2017) in their study of 274 companies, where dynamic capabilities have an indirect effect on the organization's performance. According to the authors, they contribute by reconfiguring the companies' market and operational capabilities and, therefore, they impact performance.

Regarding environmental uncertainty, both dimensions were considered as mediators of the supposed relationship. Where $\mathrm{H}_{2 \mathrm{a}}$ is confirmed, the environmental complexity mediates the relationship between productive dynamic capability and performance (0.000), mediation is considered significant ( $p$-value $=1,000>\alpha=0.05$ ).

When the environments are considered lower uncertainty the information perceived by managers will be less likely to be noticed by competitors, thus the company guarantees a certain exclusivity for decision making (Boyd \& Fulk, 1996). The authors Aragón-Correa and Sharma (2003), point out that the manager's perception of the environmental uncertainty levels can stimulate the organization developing dynamic capabilities based on the strategies taken in relation to the obtained perception.

The manager's perception of environmental complexity can influence organizational performance, as they may retreat as to investments and changes due to the number of information they find (Aragón-Correa \& Sharma, 2003). In small companies, this capability should be sand out so that 
the ventures remain active and growing. (Silveira-Martins \& Rossetto, 2018).

Thus, Silveira-Martins and Tavares (2014) point out that the manager's perception of the environment has a relationship between mercantile dynamic capability and performance. This influence is verified in this study, where complexity and dynamism mediated the relationship between productive dynamic capability and performance.

As shown, $\mathrm{H}_{2 b}$ is confirmed, the environmental dynamism mediates the relationship between productive dynamic capability and performance $(0.000)$, where it was found significant in the mediation ( $p$-value $=1,000>\alpha=0.05)$.

Once the manager realizes the uncertainty of the environment, they use the reconfiguration capability to take advantage of the new opportunities that arise with the uncertainty. This statement is lined with Teece's (2007), that argues that dynamic capabilities are related to the organization's ability to identify and shape opportunities and threats to maintain competitiveness.

Following this line of thought, Barrales-Molina, Bustinza, and Gutiérrez-Gutiérrez (2012), in its research with 200 CEOs of Spanish companies, found that only organizations in which managers perceived the organizational environment as dynamic developed the dynamic capabilities. The theorists Silveira-Martins and Tavares (2014), and Silveira-Martins and Rossetto (2018), pointed that the organizations are inserted in an uncertain environment, which may affect in some way their performance, justifying the manager's need to interpret the environment with the greatest possible success, to understand the experiences that the organization spent during its trajectory.

The result of $\mathrm{H} 2 \mathrm{~b}$ corroborates with Schilke (2014), that says that dynamic capabilities have a lesser relationship to competitive advantage in environments with poor dynamism. In other words, when the dynamism is perceived by managers as poor, dynamic capabilities will not contribute to the performance of companies as expected, as they may deprive themselves of reconfiguring and creating new resources, being at a disadvantage related to the competitors.

The environment unpredictability ultimately may affect the foreseeability of production, concerning future demands of expected production patterns (Kovach et al. 2015). This way, managers are exposed to the doubts caused by the environmental uncertainty and market requests, suffering failure risk in the production process. According to Wang (2016), when family businesses are inserted in turbulent environments, there will be a need for them to develop the capability to interpret the environment to follow the changes. Dynamic environments increase the need to change the companies, mobilizing them to use their dynamic resources and to affect the need for change (Barbero et al., 2017).

The Wang (2016) studies, with family companies, found a positive relationship between environmental dynamism, innovation, and adaptive dynamic capabilities that corroborate with Rojo et al (2018) results, in a study carried out with 302 Spanish manufacturing companies using structural equation modeling. The authors Rojo et al. (2018) confirm that the greater the environment dynamism, the greater will be the development of dynamic capabilities, such as the absorptive capability, and consequently, even greater the flexibility of the supply chain will be.

Environmental turbulence can impact firms, requiring organizations to be flexible to the changes that occur in their environment (Qureshi, Aziz \& Mian, 2017). The way small businesses deal with the environmental impacts will depend on their adaptability and their dynamic capabilities, which is why companies perceive the environment in different ways (Battisti \& Deakins, 2017). Thus, depending on the manager's understanding of the dynamism level and environmental complexity, rural agro-industrial enterprises may go into decline or, at least, not be effectively opened. 


\section{CONCLUSIONS}

The current study has sought to verify the correlation between the productive dynamic capability and performance of the southern Brazil agroindustries, and the possible mediated of the environmental uncertainty. Aiming to meet the research goal, measurement models were analyzed for each of the constructs, to subsequently perform the modeling of structural equations, correlating the variables simultaneously.

Optional measurement models were created to verify the best data fit, such models were considered feasible to hold and continue the research for the construct productive dynamic capability, and environmental uncertainty. Only the organizational performance construct presented the initial model with better statistical adjustments for the research sequence.

It was possible to identify that the productive dynamic capability is associated with the agroindustries' performance. Thus, the largest manager's investment in productive dynamic capability - automatized equipment, technology, skilled labor, production process control, production process quality, investment in distribution, product diversification - will promote a positive organizational performance.

Still another result found in the research that reveals that the uncertainty caused by the environmental variables affects the relationship between the productive dynamic capability and the organizational agroindustries' performance. Managers need to be aware of the changes that occur in the environment in which their organizations are inserted.

The managers should realize in an anticipated way the threats and opportunities, as well as efficiently interpret information passed on by that this environment. The agroindustries' performance is subordinated to the productive dynamic capability level and is still dependent on the manager's perception capability concerning the levels of environmental uncertainty available in the environment.

Agroindustries must be considered to be in highly turbulent and complex environments, due to factors such as the climate which directly affects its production, as well as economic factors, access to credit, financing, restriction of products' distribution due to legislation that prevents of transporting their product to other states if they do not meet all the requirements. With the results found it can be pointed out that one of the ways that micro and small-sized agroindustries have to overcome the complexity and the environmental dynamism is to develop and reconfigure its productive dynamic capability promoting the competitive advantage in the sector.

With the data analysis, it is possible to conclude on those variables that were excluded and also on those that followed after the confirmatory factorial analysis. In the case of the variables of the productive dynamic capability, excluded PCD1 (automated equipment), PCD2 (technological equipment), PCD3 (skilled labor), PCD4 (product diversity), and PCD5 (distribution). It can be assumed that the questions are out of the reality of the sample, and due to this when not considered in the optional model it presented better adjustments given the model that was included them. A probable explanation is that $81 \%$ of the sample is made up of rural family agroindustries, and which have some distinctions from the other unfamiliar agroindustries, which may help to explain the final research model analyzed.

This fact explains why PCD1 and PCD2 are excluded, as family agroindustries have certain difficulties for the acquisition of automated and technological equipment. Another factor that might have contributed to this result is the decision-maker's insecurity about investing in this type of equipment, which can sometimes have a high cost that impacts the company's cash flow. 
As for the exclusion of PCD3, the reason is supported by the fact that rural family agroindustries only have family collaborators, and do not hire external employees. The PCD4 exclusion can be explained by considering that rural family agroindustries must be regulated and comply with norms and laws for marketing its products in other states and municipalities, which can, sometimes, hinder distribution. This issue is also related to the agroindustries' market dispute with other food industries.

Regarding the variables that followed the optional model, PCD6 (optimized production), PCD7 (control in the production process), PCD8 (not to lose quality), it can be noticed that the researched agroindustries seek strategies to maintain quality in the production process and the final product. The process of control of the production helps companies to reduce production costs and avoid waste. It is possible to recognize the agroindustries' investment in the quality of their products, in the maintenance of their differential, and the guarantee its competitive advantage. By controlling their efforts, developing strategies, and developing their productive dynamic capability to achieve its aims.

As to the environmental uncertainty variables with the exclusion of COM3 (information dispersion) and DIN2 (competitors), it can be noticed that these agroindustries do not realize the competitors' existence in its segments. A possible explanation would be the fact that the rural family agroindustries work with a small part of the market, where there is no market competition to the point of being noticed as a threat. Another explanation may be the fact that agroindustries have differentiated products, considered unique and with added value, such as the territorial identity and cultural aspects present in the product, distinguishing them from the others.

With the questions about environmental uncertainty, considered in the final model, it is possible to perceive the difficulty in obtaining information for the decision making of these agroindustries. Respondents identified difficulty in predicting market evolution (COM1), changes in the segment (COM4), customer needs (DIN1), presenting the complex and dynamic environment that agroindustries are inserted.

The variable partners and suppliers change (DIN3) can be explained by the poor production scale and due to this the difficulty highlighted by Fernandes (2004), in acquiring packaging in a small quantity. As in packaging, such difficulty includes other products used in production. Another environmental uncertainty variable noticed by the respondents involves the change in the sector regulation (DIN4), as explained by Fernandes (2014), agroindustries need to constantly adapt to the laws that regulate them, causing uncertainty at the moment of decision making. The researched process food agroindustries, which involves several regulations on good practices in manufacturing, processing, in addition to sanitary and environmental licensing, which may undergo constant changes.

By these thoughts, it is possible to understand the context of the agroindustries surveyed in addition to the statistical analyzes singly. This occurs when identifying possible reasons for the exclusion or maintenance of construct variables, which for certain reasons may be distant from the reality of the object being searched. Finally, it can be concluded that the productive dynamic capability is correlated to the performance of the micro-sized and small-sized agroindustries of southern Brazil, and the environmental uncertainty mediates this relationship.

This research contributes to the expansion and improvement of the studies regarding productive dynamic capability, organizational performance, and environmental uncertainty, providing new results and advancing in the literature through the findings and discussion. As well as contributing to the management of rural agroindustries, it points that investment in productive dynamic capability, including distribution, product diversification, and quality favors superior performance, but environmental uncertainties. 
With the outcomes found, managers can initiate, or improve, the environment perception process in which the organization is inserted. It is suggested that the presence of a strategic environment analysis process will help improve and create new dynamic capabilities to improve performance. Through this study the agroindustries managers' have empirical evidence of how the productive dynamic capability positively provides the organization performance, becoming fundamental for its companies.

\subsection{Limitations and directions for future research}

One of the limitations reported in the study concerns the sample, since only one limited region is analyzed, the results found in this study cannot be generalized. These results are supported by the existing literature and confirmed by statistical analyses, but they should be used only for the sample analyzed. Although this study has responded to its proposed objective, any suggestions for future research can be manifested. It is proposed to expand the study the analysis in other parts of Brazil, and even abroad, with the possibility of making cross-country comparisons.

The theory about the productive dynamic capability still has discoveries to be made yet, for example, to verify the direct relationship with environmental factors. And still, analyze the moderation of environmental factors concerning productive dynamic capability and performance. Also addressing environmental munificence in these relationships of association, mediation, and moderation.

Related to the research instrument on productive dynamic capability, analyze the possibility of exchange or changing the variable PCD3 (skilled labor), including the completion of training/ courses, to be included in different contexts, as in the case of family agroindustries, validating the questionnaire.

New researches seeking to observe the agroindustry size, whether familiar or unfamiliar, the produced product type, whether cooperated or not, whether owned by monoculture or polyculture, to verify the possibilities of these factors influence the theoretical relationship proposed. Research involving specific dynamic capabilities such as absorption will help to establish how the ideas and information dissemination occurs within micro and small-scale agroindustries. The mercantile dynamic capabilities to understand how this sector deals with the competency of the adequacy of customers and the market needs.

Also, verifying the mediation of the entrepreneurial orientation in the relationship between productive dynamic capability and performance can help to understand if the dimensions of the orientation influence this relationship, as well as analyzing how the alliances' formation in the agroindustries sectors provide in the dynamic capabilities, and the same one's performance.

\section{ACKNOWLEDGMENTS}

This study was financed in part by the Coordenação de Aperfeiçoamento de Pessoal de Nível Superior - Brasil (CAPES) - Finance Code 001. 


\section{REFERENCES}

AKGÜN, A. E., KESKIN, H., \& BYRNE, J. (2008). The moderating role of environmental dynamism between firm emotional capability and performance. Journal of Organizational Change Management, 21(2), 230-252.

ALDRICH, H. E., \& PFEFFER, J. (1976). Environments of organizations. Annual Review of Sociology, 2, 79-105.

ALVES, A. C., BARBIEUX, D., REICHERT, F. M., TELLO-GAMARRA, J., \& ZAWISLAK, P.A. (2017). Innovation and dynamic capabilities of the firm: defining an assessment model. Revista de Administração de Empresas, 57(3), p. 232-244.

AMBROSINI, V., \& BOWMAN, C. (2009). What are dynamic capabilities and are they a useful construct in strategic management? International Journal of Management Reviews, 11(1), 29-49.

ANDREEVA, T., \& CHAIKA, V. (2006). Dynamic capabilities: what they need to be dynamic? (10 ed.) Working Paper. St. Petersburg State University, São Petersburgo.

ARAGÓN-CORREA, J. A., \& SHARMA, S. (2003). A contingent resource-based view of proactive corporate environmental strategy. Academy of Management Review, 28(1), 71-88.

BARRALES-MOLINA, V., BUSTINZA, O. F., \& GUTIÉRREZ-GUTIÉRREZ, L. J. (2012). Explaining the causes and effects of dynamic capabilities generation: a multiple-indicator multiple-cause modelling approach. British Journal of Management, 24(4), 571-591.

BARNEY, J. (1991). Firm resources and sustained competitive advantage. Journal of Management, 17(1), 99-120.

BARRETO, I. (2010). Dynamic capabilities: a review of past research and an agenda for the future. Journal of Management, 36(1), 256-280.

BARBERO, J. L., RAMOS, A., \& CHIANG, C. (2017). Restructuring in dynamic environments: a dynamic capabilities perspective. Industrial and Corporate Change, 26(4), 593-615.

BASTANCHURY-LÓPEZ, M. T., DE-PABLOS-HEREDERO, C., MONTES-BOTELLA, J. L., MARTíNROMO-ROMERO, S., \& GARCÍA, A. (2020). Impact of Dynamic Capabilities on Performance in Dairy Sheep Farms in Spain. Sustainability, 12(8), 3368.

BATTISTI, M., \& DEAKINS, D. (2017). The relationship between dynamic capabilities, the firm's resource base and performance in a post-disaster environment. International Small Business Journal, 35(1), 78-98.

BOYD, B. K., \& FULK, J. (1996). Executive scanning and perceived uncertainty: a multidimensional model. Journal of Management, 22(1), 1-21.

CANNON, A. R., \& ST. JOHN, C. H. (2007). Measuring environmental complexity: a theoretical and empirical assessment. Organizational Research Methods, 10(2), 296-321.

CARVAlho, C. E., \& ROSSETTO, C. R. (2014). Proposição e teste de uma escala de dinamismo, complexidade e munificência ambiental. Revista Ibero-Americana de Estratégia, 13(4), 59. 
CENTRO DE ESTUDOS AVANÇADOS EM ECONOMIA APLICADA (CEPEA). (2018). PIB-AGRO/CEPEA: agroindústria segue impulsionando PIB do agronegócio em 2018. Recuperado de: https:// www.cepea.esalq.usp.br/br/releases/pib-agro-cepea-agroindustria-segue-impulsionandopib-do-agronegocio-em-2018.aspx

CHEN, I. S., FUNG, P. K., \& YUEN, S. S. (2019). Dynamic capabilities of logistics service providers: Antecedents and performance implications. Asia Pacific Journal of Marketing and Logistics. 31(4), 1058-1075. DOI 10.1108/APJML-12-2017-0308

COLLINS, J. D., \& REUTZEL, C. R. (2017). The role of top managers in determining investment in innovation: the case of small and medium-sized enterprises in India. International Small Business Journal, 35(5), 618-638.

COSTA, L. S., \& ALMEIDA, V. M. C. (2007). Imagem do canal de distribuição como fator antecedente das dimensões da percepção do valor da marca na perspectiva do consumidor. Revista de Administração e Inovação, 4(1).

D'AVILA, O. S., \& SILVEIRA-MARTINS, E. (2017). Proposição e validação de escala para mensuração da capacidade dinâmica produtiva. Revista Eletrônica de Estratégia e Negócios, 10(1), 285311. Recuperado de: http://portaldeperiodicos.unisul.br/index.php/EeN/article/view/4803.

DAY, G. S. (1994).The capabilities of market-driven organizations. The Journal of Marketing, 58(4), 37-52.

DESARBO, W. S., BENEDETTO, A. C., SONG, M., \& SINHA, I. (2005). Revisiting the Miles and Snow strategic framework: uncovering interrelationships between strategic types, capabilities, environmental uncertainty, and firm performance. Strategic Management Journal, 26(1), 4774.

DESS, G. G., \& BEARD, D. W. (1984). Dimensions of organizational task environments. Administrative Science Quarterly, 29(1), 52-73.

DUNCAN, R. B. (1972). Characteristics of organizational environments and perceived environmental uncertainty. Administrative Science Quarterly, 17(3), 313-327.

EISENHARDT, K., \& MARTIN, J. (2000). Dynamic capabilities: what are they? Strategic Management Journal, 21(10), 1105-1121.

ESCOBAR, M. A. R. (2012). Relação das capacidades dinâmicas e orientação empreendedora com o desempenho em agências de viagens moderada pelo ambiente organizacional. (Tese de Doutorado - Universidade do Vale do Itajaí, Biguaçu). Recuperado de: https://siaiap39.univali. br/repositorio/handle/repositorio/2198.

FAN, X., THOMPSON, B., \& WANG, L. (1999). Effects of sample size, estimation methods, and model specification on structural equation modeling fit indexes. Structural Equation Modeling: A Multidisciplinary Journal, 6(1), 56-83.

FERNANDES, C. M. (2014). Agroindústrias baianas: uma análise dos limites e possibilidade do SEBRAE para o desenvolvimento das agroindústrias baianas de pequeno porte. (Dissertação de Mestrado - Universidade Federal da Bahia, Bahia). Recuperado de https://repositorio.ufba. $\mathrm{br} / \mathrm{ri} / \mathrm{handle} / \mathrm{ri} / 21714$. 
FERREIRA, J., COELHO, A., \& MOUTINHO, L. (2020). Dynamic capabilities, creativity and innovation capability and their impact on competitive advantage and firm performance: The moderating role of entrepreneurial orientation. Technovation, 92-93. DOI:/10.1016/j. technovation.2018.11.004

FISCHER, T., GEBAUER, H., GREGORY, M., REN, G., \& FLEISCH, E. (2010). Exploitation or exploration in service business development? Insights from a dynamic capabilities perspective. Journal of Service Management, 21(5), . 591-624.

FLEURY, A. (1989). Automação da Indústria Metal-Mecânica: Tendência e Organização do Trabalho na Produção. Revista da Administração, 24(3), 39-51.

FOGUESATTO, C. R., \& MACHADO, J. A. D. (2017). O processo decisório na criação de unidades que agregam valor à produção: as agroindústrias familiares. Desenvolvimento em Questão, 15(39), 301-319.

FRANK, H., GÜTTEL, W., \& KESSLER, A. (2017). Environmental dynamism, hostility, and dynamic capabilities in medium-sized enterprises. The International Journal of Entrepreneurship and Innovation, 18(3), 185-194.

FREITAS, S. L. T. U., \& SALERMO, M. S. (2018). Criação de capacitações dinâmicas e sua evolução por meio de projetos de engenharia. Revista Brasileira de Gestão e Negócios, 20(4), 495-515.

GARDELIN, J. P., ROSSETTO, C. R., \& VERDINELLI, M. A. (2013). O relacionamento entre a incerteza ambiental e o comportamento estratégico na percepção dos gestores de pequenas empresas. Revista Administração, 48(4), 702-715.

GOLL, I., \& RASHEED, A. A. (2005). The relationships between top management demographic characteristics, rational decision making, environmental munificence, and firm performance. Organization Studies, 26(7), 999-1023.

GRANT, R. M., \& JAMMINE, A. P. (1988). Performance differences between the Wrigley/Rumelt strategic categories. Strategic Management Journal, 9(4), 333-346.

GUPTA, A. K., \& GOVIDARAJAN, V. (1984). Business unit strategy, managerial characteristics, and business unit effectiveness at strategy implementation. Academy of Management Journal, $27(1), 25-41$.

HAIR, J. F. JR., ANDERSON, R. E., TATHAM, R. L., \& BLACK, W. C. (2007). Análise multivariada de dados. (5a. Ed) Porto Alegre: Bookman.

HAIR, J. F. JR., BLACK, W. C., BABIN, B. J., ANDERSON, R. E., \& TATHAM, R. L. (2009). Análise multivariada de dados. (6a. Ed). Porto Alegre: Bookman.

HARRINGTON, R. J., \& KENDALL, K. W. (2007). Uncovering the interrelationships among firm size, organizational involvement, environmental uncertainty, and implementation success. International Journal of Hospitality \& Tourism Administration, 8(2), 1-23.

HERNÁNDEZ-PERLINES, F., MORENO-GARCÍA, J., \& YÁÑEZ-ARAQUE, B. (2017). Family firm performance: the influence of entrepreneurial orientation and absorptive capacity. Psychology \& Marketing, 34(11), 1057-1068. 
INSTITUTO BRASILEIRO DE GEOGRAFIA E ESTATÍSTICA (IBGE). (2006). Censo agropecuário 2006. Rio de Janeiro. Recuperado em 11 de novembro, 2018 de: https://biblioteca.ibge.gov.br/ visualizacao/periodicos/51/agro_2006.pdf

INSTITUTO BRASILEIRO DE GEOGRAFIA E ESTATÍSTICA (2017). Censo agropecuário 2017: resultados preliminares. (pp. 01-108). Rio de Janeiro, 7. Recuperado em 11 de novembro, 2018 de: https://biblioteca.ibge.gov.br/visualizacao/periodicos/3093/agro_2017_resultados_ preliminares.pdf.

KLINGER, C. P. (2018). Relação entre orientação estratégica, diferenciação competitiva e desempenho organizacional: estudo no setor vitivinícola brasileiro. (Dissertação de Mestrado - Universidade Federal de Pelotas, Pelotas). Recuperado em 18 de agosto, 2018 de: http:// repositorio.ufpel.edu.br:8080/handle/prefix/4102?mode=full.

KHOUROH, U., SUDIRO, A., RAHAYU, M., \& INDRAWATI, N. (2020). The mediating effect of entrepreneurial marketing in the relationship between environmental turbulence and dynamic capability with sustainable competitive advantage: An empirical study in Indonesian MSMEs. Management Science Letters, 10(3), 709-720.

KOVACH, J. J., HORA, M., MANIKAS, A., \& PATEL, P. C. (2015). Firm performance in dynamic environments: the role of operational slack and operational scope. Journal of Operations Management, 37, 1-12.

LIZOTE, S. A., \& VERDINELLI, M. A. (2014). Relação entre competências empreendedoras e desempenho: um estudo em empresas prestadoras de serviços contábeis. Revista de Contabilidade e Organizações, 8(22).

LIZOTE, S. A., \& VERDINELLI, M. A. (2015). Relação entre competências empreendedoras e desempenho: um estudo em meios de hospedagem do ambiente rural. Desenvolvimento em Questão, 13(29).

LUMPKIN, G. T., \& DESS, G. G. (1996). Clarifying the entrepreneurial orientation construct and linking it to performance. Academy of Management Review, 21, 135-172.

MIKALEF, P., \& PATELI, A. (2017). Information technology-enabled dynamic capabilities and their indirect effect on competitive performance: Findings from PLS-SEM and fsQCA. Journal of Business Research, 70, 1-16.

MILLIKEN, F. J. (1987). Three types of perceived uncertainty about the environment: State, effect, and response uncertainty. Academy of Management Review, 12(1), 133-143.

MUNIZ FILHO, L. (2011). 0 efeito da munificência na relação entre o comportamento estratégico e o desempenho organizacional: um estudo setorial nas agências de viagens de Florianópolis e Balneário Camboriú/SC. (Dissertação de Mestrado - Universidade do Vale do Itajaí, Biguaçu). Recuperado de: https://siaiap39.univali.br/repositorio/handle/repositorio/1562.

MÜLLER, C. R. Direcionamentos estratégicos: um estudo avaliando a orientação empreendedora, capacidades, ambiente e desempenho de cervejarias artesanais do Brasil. (Dissertação de Mestrado - Universidade Federal de Pelotas, Pelotas). Recuperado de: http://repositorio. ufpel.edu.br:8080/handle/prefix/2961. 
MUNDIM, A. P. F., ROZENFELD, H., AMARAL, D. C., SILVA, S.L., GUERRERO, V., \& HORTA, L.C. (2002). Aplicando o cenário de desenvolvimento de produtos em um caso prático de capacitação profissional. Gestão \& Produção, 9(1), 1-16.

NAJMI, K. , KADIR, A.R. \& KADIR, M.I.A. (2018). Mediation effect of dynamic capability in the relationship between knowledge management and strategic leadership to organizational performance accountability. International Journal of Law and Management, 60(2), 517-529.

NEIROTTI, P., \& RAGUSEO, E. (2017). On the contingent value of IT-based capabilities for the competitive advantage of SMEs: mechanisms and empirical evidence. Information \& Management, 54(2), 139-153.

PRIEM, R. L., LOVE, L. G., \& SHAFFER, M. A. (2002). Executives' perceptions of uncertainty sources: a numerical taxonomy and underlying dimensions. Journal of Management, 28(6), 725-746.

QURESHI, M. S., AZIZ, N., \& MIAN, S. A. (2017). How marketing capabilities shape entrepreneurial firm's performance? Evidence from new technology based firms in turkey. Journal of Global Entrepreneurship Research, 7(10).

ROJO, A., STEVENSON, M., MONTES, F. J. L., \& PEREZ-AROSTEGUI, M. N. (2018). Supply chain flexibility in dynamic environments: The enabling role of operational absorptive capacity and organizational learning. International Journal of Operations \& Production Management, 38(3), 636-666.

ROXAS, B., ASHILL, N. \& CHADEE, D. (2017). Effects of entrepreneurial and environmental sustainability orientations on firm performance: A study of small businesses in the Philippines. Journal of Small Business Management, 55, 163-178.

SERVIÇO DE APOIO ÀS MICRO E PEQUENAS EMPRESAS (2013). Anuário do Trabalho na Micro e Pequena Empresa. (6a ed.). São Paulo. Recuperado em 23 de novembro, 2017 de http://www. sebrae.com.br/Sebrae/Portal\%20Sebrae/Anexos/Anuario\%20do\%20Trabalho\%20Na\%20 Micro\%20e\%20Pequena\%20Empresa_2013.pdf.

SCHILKE, O. (2014). On the contingent value of dynamic capabilities for competitive advantage: The nonlinear moderating effect of environmental dynamism. Strategic Management Journal, 35(2), 179-203.

SHOHAM, A., ASSERAF, Y., LEV, S., \& FIEGENBAUM, A. (2017). Marketing and technological absorptive capacities: environmental antecedents and performance outcomes in high-tech firms. Journal of Business-to-Business Marketing, 24(3), 165-182.

SILVEIRA, B. R. (2017). Orientação empreendedora, capacidades, ambiente e desempenho em cabanhas de ovinos do Brasil. (Dissertação de Mestrado - Universidade Federal de Pelotas, Pelotas). Recuperado de: http://guaiaca.ufpel.edu.br/handle/prefix/3702

SILVEIRA-MARTINS, E. (2012). Comportamento Estratégico, ambidestria, incerteza ambiental e desempenho no processo de formulação de estratégias de empresas vinícolas brasileiras. (Tese de Doutorado - Universidade do Vale do Itajaí, Biguaçu). Recuperado de: http:// siaibib01.univali.br/pdf/Elvis\%20Silveira\%20Martins.tese.pdf.

SILVEIRA-MARTINS, E., ROSSETTO, C. R., \& AÑAÑA, E. (2014). Ambidestria, exploração ou 
explotação e seus efeitos no desempenho organizacional de vinícolas brasileiras. Revista em Agronegócios e Meio Ambiente, 7(3), 707-732.

SILVEIRA-MARTINS, E., \& ROSSETTO, C. R. (2018). Mapeamento da produção científica sobre incerteza ambiental em bases internacionais. Revista de Administração da UFSM, 11(1), 78101.

SILVEIRA-MARTINS, E., \&; TAVARES, P. M. (2014). Processo de formulação de estratégias: capacidade mercadológica, incerteza ambiental e desempenho. Organizações em Contexto, 10(20)

SILVEIRA-MARTINS, E., \& ZONATTO, V. C. S. (2015). Proposição e validação de escala para mensuração de capacidade turística. Revista Turismo em Análise, 26(4).

SMART, C., \& VERTINSKY, I. (1984). Strategy and the environment: a study of corporate responses to crises. Strategic Management Journal, 5(3), 199-213.

SNYDER, H., WITELL, L., GUSTAFSSON, A., FOMBELLE, P., \& KRISTENSSON, P. (2016). Identifying categories of service innovation: a review and synthesis of the literature. Journal of Business Research, 69(7), 2401-2408.

TAKAHASHI, A. R. W., BULGACOV, S., \& GIACOMINI, M. M. (2017). Dynamic capabilities, operational capabilities (educational-marketing) and performance. Revista Brasileira de Gestão de Negócios, 19(65), 375-393.

TEECE, D. J., PISANO, G., \& SHUEN, A. (1997). Dynamic Capabilities and Strategic Management. Strategic Management Journal, 18(7), 509-533.

TEECE, D. J. (2007). Explicating dynamic capabilities: the nature and microfoundations of (sustainable) enterprise performance. Strategic Management Journal, 28(7), 1319-1350.

TEECE, D., \& LEIH, S. (2016). Uncertainty, innovation, and dynamic capabilities: An introduction. California Management Review, 58(4), 5-12.

TEECE, D. J., PETERAF, M. A., \& LEIH S. (2016). Dynamic capabilities and organizational agility: risk, uncertainty and entrepreneurial management in the innovation economy. California Management Review, 58(4), 1-33.

WANG, Y. (2016). Environmental dynamism, trust and dynamic capabilities of family businesses. International Journal of Entrepreneurial Behavior \& Research, 22(5), 643-670.

WANG, C.L., SENARATNE, C. \& RAFIQ, M. (2015). Success traps, dynamic capabilities and firm performance. British Journal of Management, 26(1), 26-44.

WANG, C. L., \& AHMED, P. K. (2007). Dynamic capabilities: A review and research agenda. International. Journal of Management Reviews, 9, 31-51.

WAQUIL, P. D., GAZOLLA, M., NEIDERLE, P., BLUME, R., BASTIAN, L., SANTOS, F., \& AMIM, M. C. (2014). O perfil da agroindústria rural no Brasil: uma análise com base nos dados do Censo Agropecuário 2006. In: Schneider; S., Ferreira, B., \& Alves, F. (Org.). Aspectos Multidimensionais da Agricultura Brasileira: diferentes visões do Censo Agropecuário 2006. (pp. 183-210). Brasília, IPEA. Recuperado em 12 de outubro, 2018 de http://ifibe.edu.br/ arq/2015081315241718255567.pdf>. 
WU, L-Y. (2006). Resources, dynamic capabilities and performance in a dynamic environment: perceptions in Taiwanese IT enterprises. Information \& Management, 43(4), 447-454.

YOO, B., DONTHU, N., \& LEE, S. (2000). An examination of selected marketing mix elements and brand equity. Journal of the Academy of Marketing Science, 28(2), 195-211. 


\section{AUTHORS}

\section{Michele Raasch}

Ph.D. candidate in Administration at the Federal University of Santa Catarina. Master degree in Territorial Development and Agro-Industrial Systems at the Federal University of Pelotas. Undergraduate degree in Administration at the Federal University of Pelotas. Florianopolis, Santa Catarina, Brazil.

E-mail: micheleraasch@hotmail.com

ORCID: https://orcid.org/0000-0002-8885-8540

\section{Elvis Silveira-Martins}

Ph.D. in Administration and Tourism at University of Vale do Itajaí, Master degree in Administration at University of Vale do Itajaí, an undergraduate degree in Administration at University of Passo Fundo. Currently is a Professor of the undergraduate's (administration) and master's courses (academic: PPGDTSA and professional: PROFIAP) at the Federal University of Pelotas, and ad hoc appraiser of the Education Department of Brazil. Pelotas, Rio Grande do Sul, Brazil.

E-mail: elvis.professor@gmail.com

ORCID: https://orcid.org/0000-0002-3189-3767

\section{Vilmar Antonio Gonçalves Tondolo}

Ph.D. in Administration at the Unisinos, with a Ph.D. at the University of Texas Pan American, Master degree in Administration at the University of Vale do Rio dos Sinos (2004), undergraduate degree in Administration at the Federal University of Rio Grande. Currently is Professor of the Faculty of Administration and Tourism at the Federal University of Pelotas. Pelotas, Rio Grande do Sul, Brazil,

E-mail: vtondolo@gmail.com

ORCID: https://orcid.org/0000-0002-3116-2585

\section{Gilnei Luiz de Moura}

Ph.D. in Administration at the School of Economics, Administration and Accounting, at the University of São Paulo, Master degree in Administration at the Federal University of Santa Catarina, undergraduate degree in Administration at the Federal University of Santa Maria. Currently is Professor of the Department of Administrative Sciences at the Federal University of Santa Maria. Santa Maria, Rio Grande do Sul, Brazil.

E-mail: mr.gmoura.ufsm@gmail.com

ORCID: https://orcid.org/0000-0003-4359-0365

\section{Contribution of authors.}

\begin{tabular}{|c|c|c|c|c|}
\hline Contribution & [Author 1] & [Author 2] & [Author 3] & [Author 4] \\
\hline 1. Definition of research problem & $\sqrt{ }$ & $\sqrt{ }$ & & \\
\hline $\begin{array}{l}\text { 2. Development of hypotheses or research } \\
\text { questions (empirical studies) }\end{array}$ & $\sqrt{ }$ & $\sqrt{ }$ & & \\
\hline \multicolumn{5}{|l|}{$\begin{array}{l}\text { 3. Development of theoretical propositions } \\
\text { (theoretical work) }\end{array}$} \\
\hline 4. Theoretical foundation / Literature review & $\sqrt{ }$ & $\checkmark$ & $\sqrt{ }$ & $\checkmark$ \\
\hline 5. Definition of methodological procedures & V & V & V & V \\
\hline 6. Data collection & V & & & \\
\hline 7. Statistical analysis & v & 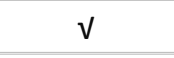 & $\sqrt{ }$ & \\
\hline 8. Analysis and interpretation of data & V & & & $\mathrm{V}$ \\
\hline 9. Critical revision of the manuscript & V & V & V & V \\
\hline 10. Manuscript writing & V & v & & \\
\hline 11. Other (please specify) & & & & \\
\hline
\end{tabular}

REV. AdM. UFSM, SANTA MARIA, V. 13, NÚMERO 5, P. 1068-1072, 2020

$$
-1072 \text { - }
$$

